\title{
Increasing Policy Success through the Use of Social Media Cross-Channels for Citizen Political Engagement
}

\author{
Christopher G. Reddick \\ Department of Public Administration \\ College of Public Policy \\ The University of Texas San Antonio \\ Texas, USA \\ chris.reddick@utsa.edu
}

\author{
Akemi Takeoka Chatfield \\ School of Computing and \\ Information Technology \\ University of Wollongong \\ Wollongong, NSW, Australia \\ akemi@uow.edu.au
}

\author{
Uuf Brajawidagda \\ Department of Informatics \\ Engineering \\ Politeknik Negeri Batam \\ Batam, Indonesia \\ uuf@polibatam.ac.id
}

\begin{abstract}
In the ubiquitous digitization era, governments increasingly adopt multi-social media channels for the purpose of facilitating citizen engagement towards enhanced government transparency, external political efficacy and policy success. However, little is known about the use of social media cross-channel information-sharing mechanisms for promoting citizen political engagement. We draw on theories of citizen interaction and citizen-centric e-governance to examine the central research question: How can citizens' become politically engaged through the use of social media cross communication channels? Specifically, we examine and explain YouTube-enabled government-to-citizens interactions and YouTubeTwitter cross-channel information-sharing behaviors among citizens in response to Jakarta, Indonesia's use of YouTube to inform citizens of the government transparency initiative. We applied social network analysis to examine the structure of and information flows within Twitter social networks formed through the use of cross-channel information-sharing mechanism by YouTube users to tweet the promotion of the YouTube-enabled government transparency videos to their Twitter followers.
\end{abstract}

\section{Introduction}

In an era of the ubiquitous digitalization of government and society, governments - not only in the U.S. but also worldwide [31] - have implemented participatory open government policies [38], which have encouraged the use of social media to facilitate greater citizen engagement $[33,35]$ and improve levels of openness, transparency and collaboration [20] towards enhanced external political efficacy $[3,32]$ in the face of the lack of government transparency which tends to sustain extant government corruption and bureaucracy problems.

While there are different definitions of political efficacy in public administration literature, we define external political efficacy as citizens' perceived government responsiveness [3, 32] to deliver citizencentric government information and services [33]. Where citizen-centric e-governance is defined as the use of IT for enhancing the ability of citizens to democratically engage with political discourse and decision-making and hence influence meaningful change in public policy. This recent strategic thinking has led to large-scale investments in social media technologies in government [1, 4, 8, 19, 28, 29]. Similarly, net-savvy citizens across the globe also invest their resources, such as time as well as technological and political knowledge, in influencing government through digital interactions which are facilitated by various social media channels and their cross-channel information sharing mechanisms. In this changing digital government landscape, governments and citizens now have the potential to lead together in making a meaningful change in the government-tocitizens relationships $[13,26,34,35]$. Despite the potential of the social media channels that are increasingly available in government and society, however, the need exists for empirical research in egovernment literature which can facilitate systematic understanding of social media-enabled active citizen engagement.

Therefore, this paper ask the following research question: How can citizens become politically engaged through the use of social media cross communication channels? In addressing this research question, we draw on the theories of citizen engagement [33, 35] and citizen-centric e-governance [34]. Specifically, we attempt to examine and explain citizens' political engagement through the use of social media and crosschannel information sharing mechanisms. As we will show, the newly elected local government leaders in 
Jakarta, Indonesia swiftly adopted YouTube as the central communication mechanism for informing citizens of the government transparency initiative as a result of long-established widespread government corruption and bureaucracy problems at the local government level. Research on e-governance articulates the importance of technology to create new relationships between citizens and their government [33] for which meaningful two-way communications are critically important.

The remainder of our paper is organized as follows. Section two presents the background for this research. Section three examines the literature on citizen-centric e-governance, citizen interaction, and social mediaenabled government transparency. Section four describes our research methodology. Section five presents of our research findings. Section six discusses the importance of our research findings. Our final section is our conclusion, including our research contribution, limitations, and future research directions.

\section{Background: "The New Jakarta"}

This paper addresses the research question in the context of a case study of Jakarta's new local government inaugurated in October 2012 and the use of YouTube video-sharing channel in government. On September 29, 2012, Joko Widodo (popularly known as Jokowi) and Basuki Tjahaja Purnama (known by his Chinese name Ahok) were elected as the Governor and the Deputy Governor, respectively, for the local government in Jakarta. The Governor won the secondround voting despite his absolute lack of experience in either national or state-level politics. Traditionally, the Governors of the Special Capital Region of Jakarta descended from Indonesian military or high politics. The Governor was the Mayor of Surakarta (a small city in the Java Island), whereas the Deputy Governor was the head of Belitung Regency (a small island in the Sumatra region). They (and the coalition of two political parties) won the second-round election over the incumbent who built his career in Jakarta politics since 1987 , by promoting their shared reform visions, "The New Jakarta" ("Jakarta Baru" in Indonesian), during the gubernatorial elections campaign. It promised the provision of citizen-centric public services through greater local government transparency and cuts in bureaucracies to improve government performance [21]. It also promised that the Governor would spend one hour in his office and the rest of the time for site visits to identify the bureaucratic inefficiency and corruption problems, provide timely decision-making, and closely monitor government performance and quality.

\section{Literature Review}

\subsection{Citizen Engagement towards Citizen- Centric E-Governance}

Drawing on prior research on models of citizen interactions with government participation [13, 34], this paper presents a theory of citizen engagement through citizen-centric e-governance. We hold that the logic and levels of citizen engagement with government on social media channels may vary from lower levels of one-way government-initiated government-to-citizen engagements ("managerial") towards higher levels of two-way, governmentinitiated, interactive government-to-citizen and citizento-government engagements ("consultative"), and highest levels of multi-directional, citizen-initiated, interactive citizen-to-government, citizen-to-citizen, and government-to-citizen engagements ("participatory"). Figure 1 below shows a typology of citizen engagement with government through a government's official YouTube channel. This theory is based on the literature on citizen-centric e-governance [33].

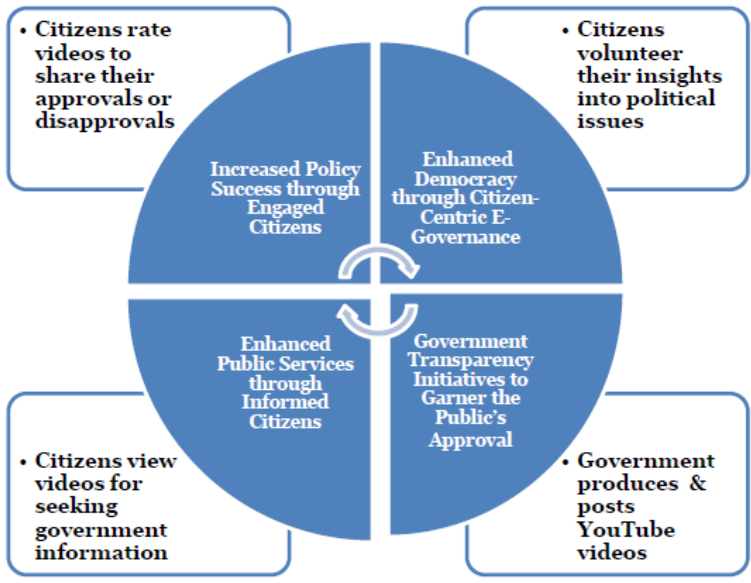

Figure 1. Logic and levels of citizen engagement applied to the research context

In the specific context of this research, the local government produces and posts YouTube videos to communicate government transparency initiatives to garner the public's approval and support. In response to this supply-side logic which drives the government transparency initiatives, the typology in Figure 1 identifies three levels of citizen engagement, through YouTube, with the government transparency initiatives, from the lowest to the highest (in the square boxes, clockwise from the bottom left). 
Here we assume that the lowest-level citizen engagement demands less personal resource commitment (e.g., time, effort, political knowledge, and analytical skills) from citizens. In contrast, the highest-level citizen engagement demands greater personal resource commitment from citizens who collectively can make meaningful change in government. However, this highest-level citizen engagement would be more difficult for government to achieve without the innovative adoption of a deliberate and democratic form of governance, citizen-centric egovernance, defined earlier, and will be discussed later in this section.

Figure 1 shows a level of citizen engagement in a square box and a logic underlying the level of citizen engagement in a piece of the pie chart. This figure indicates that government at the bottom right corner is the producer/supplier of YouTube videos to promote its supply-side logic of communicating the government transparency initiatives to garner the public's approval and support. Figure 1 shows the lowest-level citizen engagement and its logic at the bottom left corner and other levels/logics clockwise from the bottom left to the top right.

First, the lowest-level citizen engagement (vis-à-vis citizens' political apathy) is evident when net-savvy citizens seek government information and decide to view a government-produced YouTube video that describes a certain government transparency initiative on a government official YouTube channel. While citizen engagement is limited to one-way interactivity where citizens only view videos for seeking information, government may realize the logic of enhanced efficiency in public services through informed citizens.

Second, the next-level citizen engagement occurs when the citizens who have viewed the video decide to rate it for sharing their approvals or disapprovals of the specific government transparency initiative. At this level of two-way interactivity the government now has a new real-time mechanism for sensing and understanding public opinions, approvals and disapprovals on government efforts towards achieving greater government transparency in decision-making and problem-solving that would impact the public and society. Here citizens' positive ratings of governmentproduced videos may have positive effects in recommending and promoting the YouTube videos to other citizens who are not yet informed of the government transparency initiatives. This level of twoway interactivity may enable government to achieve the logic of increased policy success through engaged citizens.

Finally, the highest-level citizen engagement is observed when the citizens who have viewed and rated the video decide to volunteer their insights into political issues faced by government; namely government bureaucracy and corruption problems. Citizen viewers produce and share their comments, suggestions, criticisms, and/or solutions with political leadership as well as other citizens through the government YouTube channel. This level multidirectional interactivity and engagement on the part of citizens may enable the government to realize enhanced democracy, through citizen-centric egovernance, against the culture of the long-established government bureaucracy and corruption.

In this paper we draw on the theory of citizencentric e-governance [34], defined in the introduction to examine and explain citizens' perceived government responsiveness to the corruption problems and social media interactions among citizens in response to the government use of YouTube for government transparency. Perceived government responsiveness can be explained by this theory through understanding the critical importance of citizens for any e-governance efforts to create greater transparency and oversight. Research on e-governance articulates the importance of technology to create a new relationship between citizens and their government [33]. With the Internet, citizens can become more civically engaged and work towards the "coproduction" of government services [26]. Traditional e-government models of technology adoption for public service delivery indicate a onedirectional impact of government providing services to citizens, and citizens accepting the services they received [34]. Citizen centric e-governance, by contrast, argues for "we government", meaning that citizens work collaboratively with government and promote real and meaningful change together [26]. Efforts at creating more open government and participatory government are examples of citizencentric e-government in action [5]. The use of social media technologies is another example of engaging citizens in public policies.

The theory of citizen-centric e-governance aims to explain the postulated theoretical relationships between political efficacy and civic engagement. Political science and public administration literatures examined both internal political efficacy and external political efficacy. The former refers to an individual citizen's perception of his/her own political knowledge and/or his/her confidence in that knowledge to influence politics. In contrast, external political efficacy is defined in two different ways: (1) citizens' perceived fairness of government procedures and outcomes [9] and (2) citizens' perceived government responsiveness $[3,32]$. Here in this paper, we specifically examine external political efficacy as defined by Parent et al. [32] and Anderson [3]. Therefore, the theory postulates 
that citizens' perceptions of government responsiveness is important in empowering citizens and in response, citizens can take power and engage themselves actively and democratically to influence public affairs and policy. Citizen-centric e-governance, therefore, provides the new ability to transform the government-to-citizen and the citizen-to-citizen relationships [26, 35]. It also provides networked ordinary citizens with the new virtual public spheres for example, e-government portals, government's official YouTube channels, or social media networks in government - through which they can influence (or even co-produce) innovations in political institutions, and hence helping government moving away from traditional supply-side, government-centric provision and delivery of public services, towards more demandside, citizen-centric public services for greater citizen satisfaction and participation [13, 34].

\subsection{YouTube-Enabled Government Transparency}

Government bureaucracy and corruption diminish political accountability and legitimacy [25], erode trust in government $[22,25]$, discourage citizen engagement $[18,25]$ and hinder government performance, including the provision of effective and efficient public services [22]. When a new government is elected, a key factor influencing its success is the degree to which it can establish legitimacy among its citizens $[14,25]$. New governments often initiate institutional (or administrative) reforms for legitimacy or other reasons when their previous governments' bureaucracies have been public issues. Institutional reform in the context of government performance and new public management involves transforming government through strategic objectives of cutting the bureaucratic inefficiency and corruption and improving external political efficacy (or government responsiveness to citizen demands) [32]. Empirical studies show that bureaucratic reforms require institutional transformation, such as new transformative leadership [24] strategic use of egovernment (or government use of ICTs) and citizen participation [2, 5]. The e-government and public administration literatures suggest that institutional reform initiatives need institutional, technological and/or social mechanisms for producing desired outcomes.

In recent years there has been an increased interest in the institutional, social and economic determinants and the effects of government transparency. While conceptions of government transparency are diverse; encompassing policy-making transparency, openness of political process and public service programs priority transparency $[15,37,39]$. Specifically, empirical research on the effects of public service reform found that the institution's act of adopting administrative reform by itself produced the beneficial impact on government transparency in new Eastern European democracies [30]. Survey studies in East Central Europe explained variation in local government transparency as a function of the institutions, as opposed to socioeconomic development or locality size [11]. In another cross-national study, regression analysis found that telecommunications infrastructure and free press influenced the perceptions of government transparency in a positive and significant way [36]. Similarly, citizens' online information-seeking was positively associated with their increased support for government transparency [10], and citizens' e-participation was positively related to their assessment of local government transparency and their trust in government [23]. Despite the increased interest in government transparency, however, there has been very little research focusing on the mechanisms for advancing and communicating government transparency to stakeholders. Finally, studies on local government transparency are still very limited [37].

Earlier studies on computer-mediated government transparency [17, 27] have largely focused on the impact of government website transparency on societal trust in government, but these studies focus on neither social media technologies nor social media networks. Of these studies, only Grimmelikhuijsen and Welch [17] explored three dimensions of computer-mediated government transparency: decision-making transparency, policy information transparency, and policy outcome transparency. These studies found both the benefits and the risks involved with disclosing information. On the one hand, computer-mediated transparency is "a powerful tool to attain policy goals to transform government" [17, p.293] and provides citizens with better information [27]. On the other hand, computer-mediated transparency can drive citizens away from government, by government's strategic failure to control disclosing information; for example, information overload, cyber propaganda, and inadvertent information release [16]. Similarly, Meijer [27,p.255] warns against the complicated risks of computer-mediated transparency: "unidirectional, structured and decontexualized forms of transparency will result in a loss of societal trust." The future research directions for computer-mediated transparency would require diversity in systems of government transparency to optimize effects of computer-mediated transparency on societal trust in government [27], as well as more government transparency of quantifiable performance indicators 
and increased control of government information disclosure [16].

\section{Research Method}

To answer our research question set out in the introduction, we select the use of YouTube by the new government in the Special Capital Region of Jakarta (local government of Jakarta) and the response from the citizens as a case. YouTube has been used in prior studies to examine government transparency and citizen participation [6,7]. The selection of this case is strategic because the new government, which was inaugurated on 15 October 2014, videotaped (unedited) the government's major political activities which include reform-oriented government transparency initiative (high-level political meetings, community engagement, and site visits) and non-reform-oriented political activities (press/media conferences, ceremonies, public speeches, and making/hosting honorary visits) [7]. The videos were recorded and uploaded by the Department of Communication, Informatics and Public Relation through the government's YouTube channel "PemprovDKI" to inform citizens and promoting citizens' digital interactions with government. In the first phase of our research, we collected 266 government-generated YouTube videos. Our YouTube video data collection period was for 80 days from October 17, 2012 to January 4, 2013. Using YouTube's meta-data [actor] we selected those videos with the Governor or the Deputy Governor or both as [actor]. By excluding 16 videos that did not show either or both of these two actors, we had 250 government-produced YouTube videos for analysis. We examined the frequency of the videos posted and the number of the views.

In the phase 2, we examined citizens' cross-channel sharing of the government transparency YouTube videos through YouTube's plugins. We examined the most viewed government-generated YouTube video of November 9, 2012 to study the cross-channel sharing of the YouTube-enabled government transparency initiative videos with Twitter account holders. In other words, we want to examine citizens' cross-channel digital interactions in diffusing the most-viewed YouTube-enabled government transparency video. We selected Twitter as the other social media channel, because Twitter has the largest number of users in Indonesia than other social media channels. The video title reads: "08 Nov 2012 Wagub Bpk. Basuki T. Purnama Menerima Paparan Dinas Pekerjaan Umum" (in English, "08 Nov 2012 Deputy Governor Basuki T. Purnama receives a briefing from the Civil Works Department"). If a YouTube account holder shares this government YouTube video with Twitter account holders, a standard (but editable) tweet format is provided by YouTube. The tweet format consists of part of the YouTube title, its link and @youtube at the end.

We traced the number of YouTube viewers who shared this most-viewed government YouTube video with the query through the Topsy.com website: "08 Nov 2012 Wagub Bpk. Basuki T. Purnama Menerima Paparan". We selected the data collection period from November 9, 2012 to November 30, 2012. A total of 891 tweets were found as a result of the query. Of these tweets, we analyzed the timeline based on the timestamp of the tweets.

In the third phase, we analyzed 250,827 tweets containing the keyword "ahok" (a popular nickname of the Deputy Governor given by media and citizens of Indonesia) in the Twittersphere from October 17, 2012 and January 3, 2013 to examine citizens' digital interactions in sharing their views of the Jakarta Government's YouTube-enabled government transparency initiatives. We analyzed the 250,827 tweets by examining the timestamp of the tweets and the users who posted the tweets. The relationships between the users were finally examined through social network analysis.

\section{Findings}

\subsection{Government Production and Posting of YouTube Videos}

Figure 2 shows the number of governmentproduced YouTube videos [with the Governor, the Deputy Governor, or both identified by the meta-data, [actor] during the data collection period. On average, more than 3 videos were uploaded daily, ranging from 1 video to 13 videos. On average, each video was viewed by more than 31,000 citizens. The average number of the views is $4.75 \%$ of the videos with more than 10,000 views [12]. 


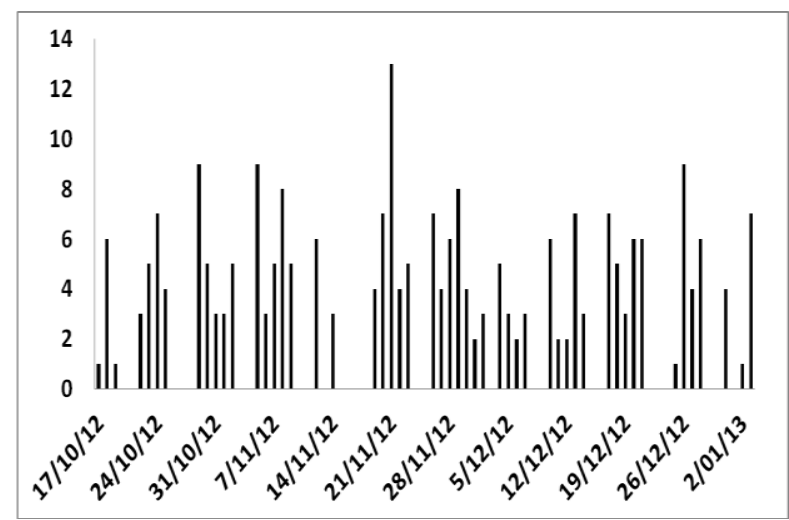

Figure 2. Number of video uploaded daily

\subsection{Citizens' Viewing of Government YouTube Videos}

Figure 3 shows the frequency distribution of a total of 7.8 million viewers on the temporal $\mathrm{x}$-axis.

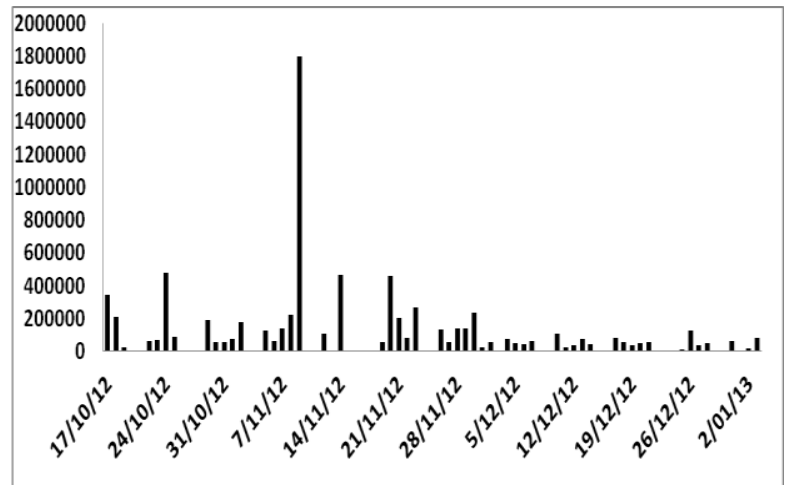

Figure 3. Number of government YouTube video viewers

The videos published on November 9, 2012 attracted almost 1.8 million viewers $(23 \%$ of the total viewers). There were 5 YouTube videos uploaded on this day, which included 1 video of the governor's activities and 4 videos of the deputy governor's activities. Of the 5 videos, the deputy governor video attracted more than 1.4 million viewers (18\% of the total viewers).

Despite the fact that the average length of the government-produced videos is over 36 minutes, they attracted more than 7.8 million viewers during the data collection period. Importantly, this critical mass seems to indicate that Indonesian citizens did not show political apathy in their responses to the YouTubeenabled government transparency initiative communicated by the new political leadership. In other words, those citizens with YouTube accounts demonstrated high-level political interests in the local government's attempts to make government more open and more transparent for the public.

\subsection{Citizens' Cross-Channel Sharing of Government Transparency YouTube Videos}

YouTube as a video sharing channel allows its account holders to share user-generated videos with other social media channels to facilitate wider digital interactions. Figure 4 shows the sharing functions YouTube provides for its account holders to easily share and diffuse their favorite videos with other social media users. Other social media channels YouTube supports include: Facebook, Twitter, Google+, Reddit, Blogger, Tumblr, Pinterest, LinkedIn, among others.

\section{Share this video Embed Email

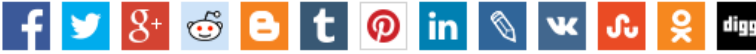 \\ $\square$ Share with playlist starting from current video - \\ Figure 4. YouTube feature to share the video with other social media channels}

The most viewed government-generated YouTube video of November 9, 2012 was examined to study the cross-channel sharing of the YouTube-enabled government transparency initiative videos with Twitter account holders. A total of 891 tweets were collected through the query discussed in our Methodology section. Figure 5 shows a trend line graph of the YouTube sharing between YouTube viewers and Twitter users. Figure 5 shows that the cross-channel video sharing peaked on November 13, 2012 - four days after the most-viewed government YouTube video was posted.

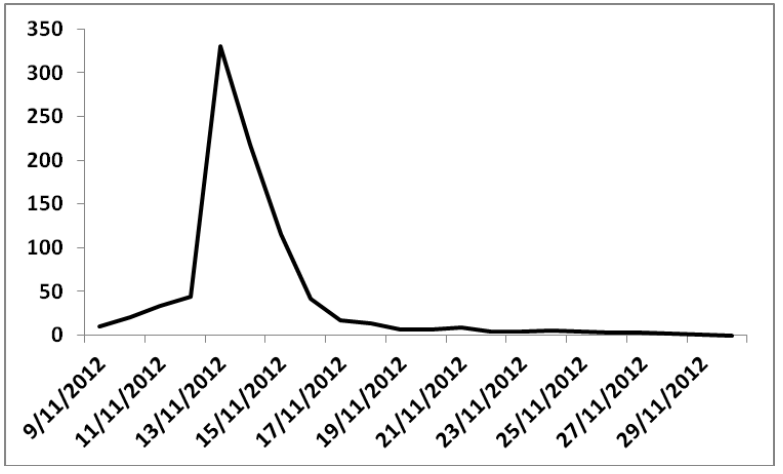

Figure 5. Trend line graph of cross-channel video sharing: YouTube and Twitter 


\subsection{Cross-Channel Sharing of YouTube- Enabled Government Transparency Articles}

The web 2.0 technologies enable citizens to generate and modify user-generated information content. Citizens can post their comments on a website using a simple function provided by web 2.0 technologies. This function was widely adopted by most of the online news media, where readers are invited to provide comments on specific online news articles. With the growth of social media channels, users not only discuss the content of the online mass media's website, but also bring the discussion of the specific news article content to any of their social media channels of choice. This can be done by posting the website link to their social media channels. Many social media plugins are available to allow users for sharing the website link or content to users' social media accounts.

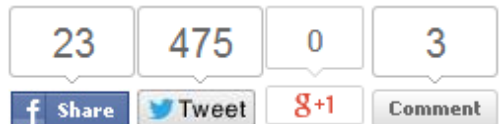

Figure 6. Social media plugins offered by Detik.com

Figure 6 shows social media plugins that are available through Detik.com website, one of the leading online news content provider in Indonesia. In comparison to the YouTube cross-channel video sharing function, these plugins are simpler, since they only allow users (1) to share the news articles with users of Facebook, Twitter, and Google+ and (2) to post their comments. The plugins also indicate the number of sharing made through Facebook, Twitter or Google+ as well as the number of comments generated for each of online news articles.

\subsection{Citizens' Tweets on YouTube-Enabled Government Transparency}

We analyzed 250,827 tweets containing "ahok" in the Twittersphere from October 17, 2012 and January 3, 2013. Our aim was to examine citizens' digital interactions in sharing their views of the Jakarta Government's YouTube-enabled government transparency initiative. Figure 7 shows a trend line graph of citizens' tweets.

We found that the discussion of the YouTube video use for government transparency by the Jakarta local government was started immediately after the inauguration of the new political leadership. Of the 250,827 tweets, the first tweets informed of the launch of the official Jakarta Government YouTube channel were issued on October 18, 2012. One tweet shows that users remarked positively: "For you who have YouTube Account, please subscribe channel 'PemprovDKI'. The openness of Jokowi Ahok is for citizens to govern". Similarly, another tweet states that "The Youtube Channel of PemrovDKI... let us watch Jokowi-Ahok's performance youtube.com/user/PemprovDK." Arguably, the two tweets urge other online citizens to watch JokowiAhok government through the government YouTube channel. The two tweets explicitly mention the "PemprovDKI" (the official Jakarta Government's YouTube channel) in their tweets. The two tweets were re-tweeted by other online citizens. While the Jakarta government adopted the use of YouTube channel immediately after the inauguration, it opened its official Twitter account (@PemprovDKI1) much later on October 30, 2012. This may explain why the government did not join the online citizens in promoting the viewing of their YouTube-enabled government transparency initiative sooner.

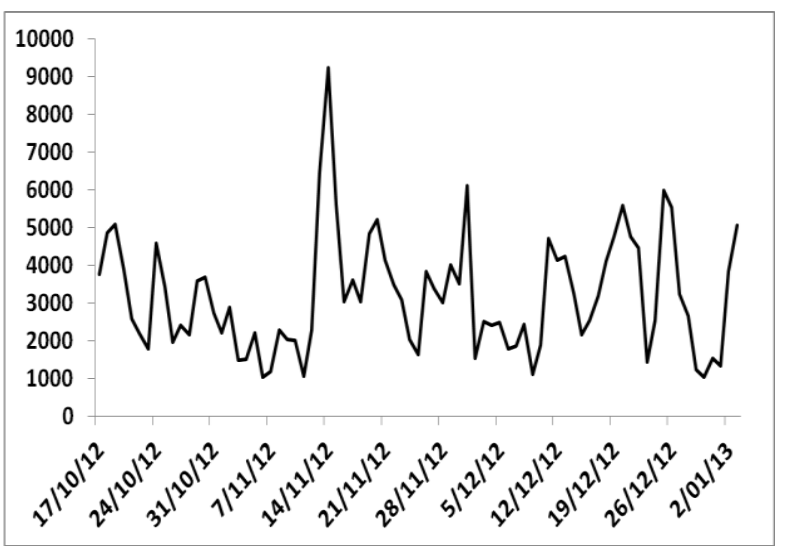

Figure 7. Trend line graph of "Ahok" in Tweets

In addition to the citizens' tweets for promoting awareness of YouTube-enabled government transparency initiative, we explored whether or not these online citizens discussed the most viewed video earlier than the mass media did. The government YouTube video was uploaded at 7:10:11 am on November 9, 2012. We found that the first tweet informing the most viewed government YouTube video was posted by a citizen at 9:52 pm on November 9,2012 . These two timestamps show the difference of about 15 hours. Despite the time delay, astute citizens showed fairly timely awareness of the YouTubeenabled government transparency initiative within the Twitter social networks. However, the tweet did not provide the link to the video. It only states: "Have you seen video uploaded by the Jakarta Government's 
public affair that Ahok had a meeting with the Civil Works Department? Must See!".

\subsection{Social Network Citizens' Interactions within Online Social Networks}

Based on the findings discussed above, digital interactions aimed for information sharing within the Twittersphere seems to influence the number of the YouTube viewers we discussed earlier in this paper. To better understand the citizens who have contributed to the sharing of the video or news articles, we performed social network analysis of the Twitter users who embedded the keyword "ahok" in their tweets, from November 1 to November 19, 2012. We selected this keyword because the most viewed governmentgenerated YouTube video featured the Deputy Governor's reform-oriented policy-making activities. The online social network formed by Twitter users using this keyword is presented in Figure 8. The (larger) size of a given node (Twitter account holder) is determined by the (greater) number of followers of the node. The (larger) label font size represents the (greater) in-degree centrality, which refers to the number of connections or links to a node. The bigger the node size or label font size is, the bigger its follower are or its in-degree centrality is.

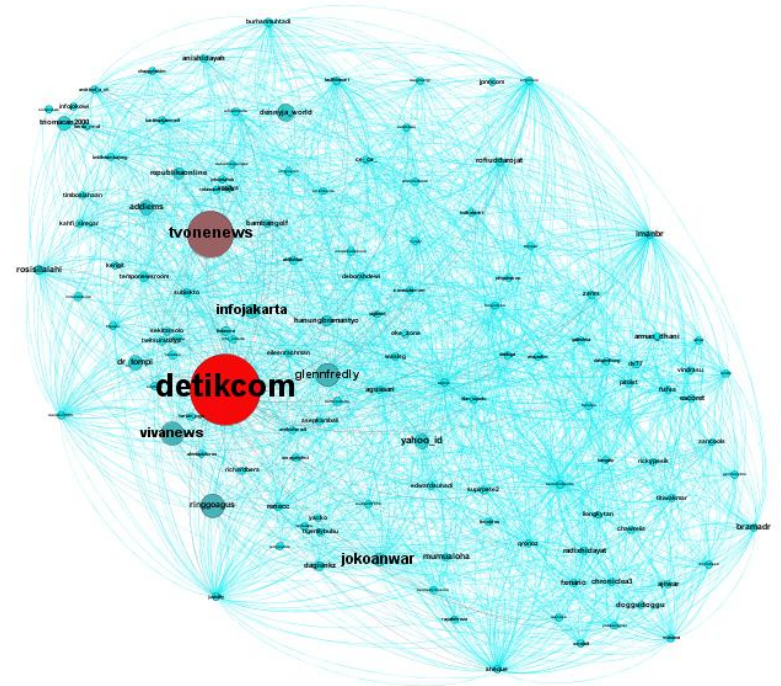

Figure 8. Online social networks formed by Twitter users of "Ahok"

Table 1 shows more detailed findings of 10 of the largest nodes shown in Figure 8 above. The highest indegree centrality found was 1,710 of online mass media, detikcom. Table 1 lists 5 mass media and 5 citizens. Our analysis shows that @detikcom, the official Twitter account of the online mass media
Detik.com, is the largest node in the network that we examined earlier in this paper. Overall, the nodes with the largest influence on digital interaction networks are from mass media and well known artists. Among of the mass media are detikcom, tvonenews, vivanews and yahoo_id and artists, while the artists are jokoanwar, glennfredly, dr_tompi, ringgoagus and addiems.

Table 1. 15 Largest nodes in the information sharing network

\begin{tabular}{|l|r|r|l|}
\hline Twitter Account & Follower & $\begin{array}{c}\text { In- } \\
\text { Degree }\end{array}$ & $\begin{array}{l}\text { Account } \\
\text { Description }\end{array}$ \\
\hline detikcom & $6,964,385$ & 1,710 & Mass Media \\
\hline tvonenews & $4,283,009$ & 752 & Mass Media \\
\hline jokoanwar & 570,077 & 717 & $\begin{array}{l}\text { Citizen } \\
\text { (Film } \\
\text { Producer) }\end{array}$ \\
\hline vivanews & $1,721,354$ & 648 & Mass Media \\
\hline infojakarta & 715,829 & 615 & Mass Media \\
\hline glennfredly & $1,742,574$ & 525 & $\begin{array}{l}\text { Citizen } \\
\text { (Artist) }\end{array}$ \\
\hline yahoo_id & 801,244 & 430 & Mass Media \\
\hline dr_tompi & 750,738 & 380 & $\begin{array}{l}\text { Citizen } \\
\text { (Artist) }\end{array}$ \\
\hline ringgoagus & $1,799,003$ & 361 & $\begin{array}{l}\text { Citizen } \\
\text { (Artist) }\end{array}$ \\
\hline addiems & 731,524 & 358 & $\begin{array}{l}\text { Citizen } \\
\text { (Artist) }\end{array}$ \\
\hline
\end{tabular}

\section{Discussion and Conclusion}

In examining our research question set out in the introduction, we draw on the theory of citizen-centric e-governance [34]. Specifically, we examined citizens' political engagement through the use of social media cross communication channels among net-savvy citizens in response to the existing wide-spread government corruption and the external political efficacy displayed by newly elected local government leaders in Jakarta, Indonesia. Our social network analysis findings indicated that the online social networks formed by Twitter users were very active with Indonesia's well-known online mass media and well-known citizens as big nodes with many interactions with other nodes. This also suggests that society in general was digitally interacting to support the government's use of YouTube to improve government responsiveness to the age-old complex government bureaucracy and corruption problems, which the previous government leaders had evidently failed to solve. The two sample tweets posted by 
citizens show their support and promotion of the YouTube-enabled government transparency initiative.

We found evidence of evolving cross-channel social networks which are self-organizing in response to the innovative government transparency initiative using YouTube and its visual and captivating messages. Based on the profile of a sample of 10 largest nodes in our cases study, social media was used to make the murky process more visually clear to the networked, but otherwise ordinary citizens who are not political activists. Our results indicate the criticality of how the government uses social media platforms for its transparency initiative in facilitating and enabling the desired policy outcomes.

Jakarta's local government has faced the serious government bureaucracy and corruption problems for a long time. We have analyzed citizens' digital interactions with YouTube-enabled government transparency initiative. In this research, we used the number of given YouTube videos downloaded by citizens as a proxy for their approval or disapproval. The higher the number is, the higher citizens approve government responsiveness to the bureaucracy and corruption problems. As shown in Figure 2, 7.8 million citizens viewed the government-generated YouTube videos fairly regularly and consistently during the data collection period. However, the videos published on November 9, 2012 attracted almost 1.8 million viewers (23\% of the total viewers). These findings indicate that online citizens' arguably have high-level engagement in supporting and approving their perceived government responsiveness to the serious government bureaucracy and corruption problems. In contrast to the citizens' digital engagements, online mass media's engagements with the YouTube-enabled government transparency initiative are much more lukewarm and underwhelming, with a very low percentage of their news articles sourced from the government-generated YouTube videos.

Overall, these findings provide preliminary evidence for the utility of our research framework shown in Figure 1. In this framework, we demonstrate theories of citizen engagement and citizen-centric egovernance through different levels of social mediaenabled citizens' political engagement and digital interactions in response to societal problems [25, 34]. This theory-driven empirical study using social network analysis can contribute to the e-government literature by describing how a critical mass of citizens have digitally engaged with the government transparency initiative. Supporing our theoretical framework in Figure 1, net-savvy citizens on YouTube helped the new political leadership towards increased policy success. This was done by viewing the YouTube videos, approving the government transparency efforts, and through the YouTube's cross-channel informationsharing mechanisms urging Twitter users to watch the government transparency initiative YouTube videos. Without the viewing of the government YouTube videos and the promoting of the YouTube-enabled government transparency initiative, the likelihood of policy success especially in the research context of the Jakarta local government would be very low. However, this research did not find evidence for the highest-level citizen political engagement towards citizen-centric e-governance as shown in Figure 1.

However, this research has some limitations including the relatively short data collection period of 70 days and the use of Topsy.com, a third party provider of tweet data, which does not assure random sampling of all tweet data for social network analysis. Our future research directions include longitudinal study over a longer data collection period and case study research on a sample of social media users on external political efficacy and citizen-centric egovernance for further development of government transparency.

\section{References}

[1] Abdelsalam, H.M., Reddick, C.G., Gamal, S., and Alshaar, A., "Social media in Egyptian government websites: Presence, usage, and effectiveness", Government Information Quarterly, 30(4), 2013, pp. 406-416.

[2] Ahn, M.J., and Bretschneider, S., "Politics of egovernment: E-government and the political control of bureaucracy", Public Administration Review, 71(3), 2011, pp. 414-424.

[3] Anderson, M.R., "Community psychology, political efficacy, and trust", Political Psychology, 31(1), 2010, pp. 59-84.

[4] Bekkers, V., Edwards, A., and de Kool, D., "Social media monitoring: Responsive governance in the shadow of surveillance?", Government Information Quarterly, 30(4), 2013, pp. 335-342.

[5] Bertot, J.C., Jaeger, P.T., and Grimes, J.M., "Using ICTs to create a culture of transparency: E-government and social media as openness and anti-corruption tools for societies", Government Information Quarterly, 27(3), 2010, pp. 264271.

[6] Burgess, J., and Green, J., YouTube: Online video and participatory culture, Polity Press, MA, USA, 2009.

[7] Chatfield, A.T., and Brajawidagda, U., "Political will and strategic use of YouTube to advancing government transparency: An analysis of Jakarta government-generated YouTube videos", in (Wimmer, M.A., Janssen, M., and Scholl, H.J., 'eds.'): Electronic Government, Springer, 2013, pp. 26-37.

[8] Chatfield, A.T., Scholl, H.J., and Brajawidagda, U., "Tsunami early warnings via Twitter in government: Netsavvy citizens' co-production of time-critical public information services", Government Information Quarterly, 30(4), 2013, pp. 377-386. 
[9] Craig, S.C., Niemi, R.G., and Silver, G.E., "Political efficacy and trust: A report on the NES pilot study items", Political Behavior, 12(3), 1990, pp. 289-314.

[10] Cuillier, D., and Piotrowski, S.J., "Internet informationseeking and its relation to support for access to government records", Government Information Quarterly, 26(3), 2009, pp. 441-449.

[11] Dowley, K.M., "Local government transparency in East Central Europe", Local Government Studies, 32(5), 2006, pp. 563-583.

[12] Frommer, D., and Angelova, K., http://www.businessinsider.com.au/chart-of-the-dayyoutube-videos-by-views-2009-5? r=US\&IR=T, accessed June 8, 2016.

[13] Gauld, R., Goldfinch, S., and Horsburgh, S., "Do they want it? Do they use it? The 'demand-side' of e-government in Australia and New Zealand", Government Information Quarterly, 27(2), 2010, pp. 177-186.

[14] Gibson, J.L., Overcoming apartheid: Can truth reconcile a divided nation?, Russel Sage, New York, 2004.

[15] Grigorescu, A., "International organizations and government transparency: Linking the international and domestic realms", International Studies Quarterly, 47(4), 2003, pp. 643-667.

[16] Grimmelikhuijsen, S., "A good man but a bad wizard. About the limits and future of transparency of democratic governments", Information Polity, 17(3-4), 2012, pp. 293302.

[17] Grimmelikhuijsen, S., and Welch, E.W., "Developing and testing a theoretical framework for computer-mediated transparency of local governments", Public Administration Review, 72(4), 2012, pp. 562-571.

[18] Hetherington, M.J., Why trust matters: Declining political trust and the demise of American liberalism, Princeton University Press, Princeton, NJ, 2005.

[19] Hoffman, L.H., Jones, P.E., and Young, D.G., "Does my comment count? Perceptions of political participation in an online environment", Computers in Human Behavior, 29(6), 2013, pp. 2248-2256.

[20] Jaeger, P.T., and Bertot, J.C., "Transparency and technological change: Ensuring equal and sustained public access to government information", Government Information Quarterly, 27(4), 2010, pp. 371-376.

[21] Jakarta Baru, http://jakartabaru.co/home/visimisi, accessed January 25, 2013.

[22] Kim, S., "Public trust in government in Japan and south Korea: Does the rise of critical citizens matter?", Public Administration Review, 70(5), 2010, pp. 801-810.

[23] Kim, S., and Lee, J., "E-participation, transparency, and trust in local government", Public Administration Review, 72(6), 2012, pp. 819-828.

[24] Lee, K.R., and Lee, K.-S., "The Korean government's electronic record management reform: The promise and perils of digital democratization", Government Information Quarterly, 26(3), 2009, pp. 525-535.
[25] Levi, M., Sacks, A., and Tyler, T., "Conceptualizing legitimacy, measuring legitimating beliefs", American Behavioral Scientist, 53(3), 2009, pp. 354-375.

[26] Linders, D., "From e-government to we-government: Defining a typology for citizen coproduction in the age of social media", Government Information Quarterly, 29(4), 2012, pp. 446-454.

[27] Meijer, A., "Understanding modern transparency", International Review of Administrative Sciences, 75(2), 2009, pp. 255-269.

[28] Mergel, I., "Social media adoption and resulting tactics in the U.S. federal government", Government Information Quarterly, 30(2), 2013, pp. 123-130.

[29] Mossberger, K., Wu, Y., and Crawford, J., "Connecting citizens and local governments? Social media and interactivity in major U.S. cities", Government Information Quarterly, 30(4), 2013, pp. 351-358.

[30] Neshkova, M.I., and Kostadinova, T., "The effectiveness of administrative reform in new democracies", Public Administration Review, 72(3), 2012, pp. 324-333.

[31] Open Government Partnership, http://www.opengovpartnership.org/countries, accessed August 1, 2014.

[32] Parent, M., Vandebeek, C.A., and Gemino, A.C., "Building citizen trust through e-government", Government Information Quarterly, 22(4), 2005, pp. 720-736.

[33] Reddick, C.G., "Citizen interaction with e-government: From the streets to servers?", Government Information Quarterly, 22(1), 2005, pp. 38-57.

[34] Reddick, C.G., "Citizen-centric e-governance and innovative developments of public services", in (Ari-Veikko Anttiroiko, S.J.B., Pekka Valkama, 'ed.' Innovation and the Public Sector, Volume 15: Innovations in Public Governance edn., IOS Press, Amsterdam, 2011, pp. 217-233.

[35] Reddick, C.G., "Citizen interaction and e-government: Evidence for the managerial, consultative, and participatory models", Transforming Government: People, Process and Policy, 5(2), 2011, pp. 167-184.

[36] Relly, J.E., and Sabharwal, M., "Perceptions of transparency of government policymaking: A cross-national study", Government Information Quarterly, 26(1), 2009, pp. 148-157.

[37] Sol, D.A.d., "The institutional, economic and social determinants of local government transparency", Journal of Economic Policy Reform, 16(1), 2013, pp. 90-107.

[38] The White House, https://www.whitehouse.gov/sites/default/files/opengov_repo rt.pdf, accessed December 10, 2009.

[39] von Haldenwang, C., "Electronic government (Egovernment) and development", European Journal of Development Research, 16(2), 2004, pp. 417-432. 